\section{Søvnproblemer etter brystkreft}

\author{
Skulderplager etter brystkreft er \\ en viktig årsak til søvnproblemer.
}

Hos brystkreftbehandlede kvinner er plager i arm/skulder i form av smerter, lymfødem og/eller nedsatt bevegelighet hyppige bivirkninger etter kirurgi og strålebehandling mot aksillen.

Vi har gjort en studie med 337 kvinner behandlet for brystkreft stadium 2/3 ved Oslo universitetssykehus, Radiumhospitalet. Median oppfølgingstid var 3,9 år (1). 37\% rapporterte at de hadde smerter, $21 \%$ hadde lymfødem og $15 \%$ redusert bevegelighet. $30 \%$ hadde søvnproblemer i form av innsovningsvansker og/eller tidlig oppvåkning. I et aldersmatchet kontrollmateriale fra Helseunders $\varnothing$ kelsen i Nord-Trøndelag (HUNT-2) hadde $18 \%$ av kvinnene søvnproblemer. Sammenliknet med dem brukte kreftoverleverne mer sovemidler, de følte seg mer trette og hadde høyere angstnivå.

En etterunders $\varnothing$ kelse (median 2,5 år senere) viste at $20 \%$ rapporterte søvnproblemer ved begge unders $\emptyset$ kelsestidspunkter. Smer- ter i arm/skulder og nedsatt bevegelighet i første undersøkelse predikerte søvnproblemer i neste. Sterkeste prediktor var likevel bruk av sovemidler ved første undersøkelse.

Én tolking er at plager i arm/skulder kommer i tillegg til andre kjente årsaksfaktorer ved søvnproblemer hos brystkreftoverlevere. $15 \%$ av brystkreftkvinnene brukte sovemidler, mot $4 \%$ av kontrollkvinnene. Av kvinnene med søvnplager brukte $36 \%$ sovemidler på tross av mangelfull effekt. Dette reiser spørsmål ved forskrivningspraksisen når det gjelder sovemidler til kvinner som har vært behandlet for brystkreft. Våre funn peker også på adekvat behandling av plager i arm/ skulder kan bidra til å redusere søvnproblemene i denne pasientgruppen.

\section{Alv A. Dahl}

alvdah@ous-hf.no

Oslo universitetssykehus, Radiumhospitalet

\section{Litteratur}

1. Dahl AA, Nesvold IL, Reinertsen KV et al. Arm/ shoulder problems and insomnia symptoms in breast cancer survivors: cross-sectional-controlled and longitudinal observations. Sleep Med 2011 12: $584-90$.

\title{
Væskeresuscitering kan være skadelig i ressursfattige land
}

\section{Volumekspansjon står sentralt i behandlingen av pasienter med dårlig sirku- lasjon. At en fersk studie viser at infeksjonssyke barn som fikk tidlig væske- støt hadde høyere mortalitet enn kontrollgruppen, er oppsiktsvekkende.}

En randomisert, kontrollert studie med 3141 barn (i alderen 60 dager-12 år) i Uganda, Kenya og Tanzania (1) var designet for å sammenlikne fysiologisk saltvann og albumin til væskeresuscitering $(20-40 \mathrm{ml} / \mathrm{kg}$ over 1 t) hos barn med feber, påvirket bevissthet og/eller respirasjonsbesvær samt tegn på nedsatt perfusjon (definert ved kapillær refylling > 3 sek, kalde underekstremiteter eller alvorlig takykardi). Det var ingen forskjell idødelighet - av de 1050 barna som fikk albumin, døde 111 innen 48 timer $(10,6 \%)$ og av de 1047 som fikk saltvann, døde $110(10,5 \%)$. Derimot døde kun 76 av 1044 barn $(7,3 \%)$ innen 48 timer i kontrollgruppen, som ikke fikk væskestøt [rettet].

Alle fikk væske etter basalbehov og standard infeksjonsbehandling. I tiden etter de første to døgnene var det ingen statistisk signifikant forskjell imortalitet mellom gruppene, slik at resultatene sto seg etter fire uker. Subgruppeanalyser viste ikke gevinst av væskebehandling, verken ved malaria, anemi, koma eller laktacidose.
Årsaken til utfallet er uklar. Lungeødem og økt intrakranialt trykk ble registrert i studien, men dette forklarte ikke den økte dødeligheten. Forfatterne spekulerer i om væsketilførselen opphever den hensiktsmessige vasokonstriksjonen pasienten ellers har pga. katekolaminaktivering, eventuelt at det dreier seg om reperfusjonsskader.

Dette bør føre til at vi revurderer vår oppfatning av septisk sjokk der det er ressursfattigdom. Resultatene kan dog ikke ekstrapoleres direkte til vestlige land eller til andre årsaker til sirkulasjonssvikt, som dehydrering ved gastroenteritt, underernæring, kirurgi eller liknende (2).

\section{Kristoffer Brodwall \\ kristoffer.brodwall@gmail.com \\ Barneklinikken}

Haukeland universitetssykehus

\section{Litteratur}

1. Maitland K, Kiguli S, Opoka RO et al. Mortality after fluid bolus in African children with severe infection. N Engl J Med 2011; e-publisert 26.5.

2. Myburgh JA. Fluid resuscitation in acute illness time to reappraise the basics. N Engl J Med 2011; e-publisert 26.5.

\section{Hvilke studier har oftest subgruppe- analyser?}

\section{I randomiserte industristøttede}

studier publisert i tidsskrifter med

høy impaktfaktor rapporteres det

oftest om subgruppeanalyser av

\section{pasienter.}

Subgruppeanalyser er vanlige i randomiserte studier. Oppdaterte kriterier for å vurdere gyldighet av slike analyser er nylig publisert (1). Nå har en internasjonal forskergruppe med norsk deltakelse undersøkt hvilke typer studier man har subgruppeanalyser i (2).

Den systematiske oversikten omfattet 469 randomiserte kontrollerte studier publisert i 118 ledende kliniske tidsskrifter i 2007. Tidsskrifter med høy og lav impaktfaktor i forholdet 1: 1 ble tilfeldig plukket ut. I $44 \%$ rapporterte man om subgruppeanalyser. Resultatene viste at studier støttet av industrien oftere hadde subgruppeanalyser enn de som ikke var støttet av industrien, men kun hvis det primære utfallet ikke var statistisk signifikant. Tidsskrifter med høy impaktfaktor hadde større sannsynlighet for å rapportere om subgruppeanalyser enn tidsskrifter med lav impaktfaktor. Dette gjaldt også ikke-kirurgiske studier.

- En forutsetning for å kunne hevde at behandling har ulik relativ effekt i subgrupper av pasienter er at analysene er planlagt og utført korrekt og at tolkingen er adekvat. Dataekstraksjonen i denne systematiske oversikten viser at publiserte studier sjelden fyller disse forutsetningene, sier en av forfatterne, lege og forsker Per Olav Vandvik ved Nasjonalt kunnskapssenter for helsetjenesten.

- Med fare for forenkling er budskapet til klinikere: Ikke stol på subgruppeanalyser. Overraskende sjelden kan man konkludere med at behandling har ulik relativ effekt i subgrupper. Derimot har behandling ulik absolutt effekt basert på forskjellig utgangsrisiko for hendelser. For eksempel vil 80åringer ha større absolutt effekt av statiner enn 60-åringer pga. større risiko for kardiovaskulœre hendelser, sier Vandvik.

\section{Trine B. Haugen}

trine.b.haugen@hf.hio.no

Tidsskriftet

\section{Litteratur}

1. Sun X, Briel M, Walter SD et al. Is a subgroup effect believable? Updating criteria to evaluate the credibility of subgroup analyses. BMJ 2010; 340: c117.

2. Sun $X$, Briel M, Busse JW et al. The influence of study characteristics on reporting of subgroup analyses in randomised controlled trials: systematic review. BMJ 2011; 342: d1569. 